\title{
The Role of Language Objectives: Strengthening Math and Science Teachers' Language Awareness with Emergent Bilinguals in Secondary Classrooms ${ }^{1}$
}

El rol de los objetivos de lenguaje: fortaleciendo la conciencia lingüística de los maestros de matemáticas y ciencias con los bilingües emergentes en las clases secundarias

O papel dos objetivos da linguagem: fortalecer a consciência linguística dos professores de matemática e ciências com os bilíngues emergentes nas aulas secundárias

Holly Hansen-Thomas

Texas Woman's University, United States of America hhansenthomas@twu.edu orcid.org/00oo-0002-4962-9446

Juliet Langman University of Texas at San Antonio, United States of America juliet.langman@utsa.edu orcid.org/0000-0002-III3-4085

Tiffany Farias Sokoloski Yes! Our Kids Can, United States of America tsokoloski@gmail.com orcid.org/0000-0003-0177-9629

1 The work reported here was supported by a grant (T365Z120026) from the Office of English Language Acquisition of the US Department of Education. The opinions expressed are those of the authors and do not represent views of the Office of English Language Acquisition or the US Department of Education. Hearty gratitude is extended to all teachers and students who helped bring this project to fruition.

Received: 22-10-2018

Accepted by peers: 06-02-2019
Sent for peer review: 22-10-2018

Approved: $13-02-2019$

To reference this article (APA) / Para citar este artículo (APA) / Para citar este artigo (APA) Hansen-Thomas, H., Langman, J., \& Farias, T. (2018). The role of language objectives: Strengthening math and science teachers' language awareness with emergent bilinguals in secondary classrooms. LACLIL, 11(2), 193-214. DOI: 10.5294/laclil.2018.11.2.2 
ABSTRACT. This study focuses on the linguistic foundation of sound pedagogic practices related to non-language content areas referring especially to language objectives; it employ Tharp and Gallimore's theory on learning: making teaching visible in order to develop the students' thinking. In the contexts of training both before and after service, a study was conducted on how secondary-science and math teachers contextualize their own teaching according to Emergent Bilinguals (EBs) by using interviews and focus group discussions. Findings reveal that teachers gradually develop an increased sense of importance of language objectives over time. The strengths and challenges highlighted through the study show the need for increased teacher training in the area of teacher language awareness (TLA). So far, the predominance of TLA in the classrooms has been and employ language objectives in their teaching, this study proposes a few ways to provide math and science teachers with tools for incorporating language into everyday teaching practices. The present study further supports the call for attention on the needs of all content teachers who work with EBs on training in language awareness.

Keywords (Source: Unesco Thesaurus): Math and science teaching; teacher language awareness; teaching practice; emergent bilinguals; language objectives.

RESUMEN. El objetivo de este estudio es ilustrar los fundamentos lingüísticos de las buenas prácticas de enseñanza relacionadas con las áreas de contenido no lingüístico, especialmente en relación con los objetivos lingüísticos; empleamos una extensión de la metáfora de aprendizaje de Tharp y Gallimore: hacer visible la enseñanza para desarrollar el pensamiento de los estudiantes. En el contexto de la capacitación de los docentes antes y después de empezar a ejercer, examinamos cómo los profesores de ciencias secundarias y matemáticas enmarcan su propia enseñanza de acuerdo con los bilingües emergentes (BE). A través de entrevistas y grupos focales, encontramos que los maestros desarrollan un mayor sentido de la importancia de los objetivos del lenguaje a lo largo del tiempo. Un examen de las fortalezas y desafíos percibidos señala la necesidad de una mayor formación docente en el área de la consciencia lingüística de los profesores (TLA). Hasta la fecha, el predominio de la investigación de TLA examina las aulas de clases de los profesores de idiomas (incluyendo L2). Sobre la base de nuestro análisis de cómo los maestros de contenido definen y emplean los objetivos de lenguaje en su enseñanza, proponemos investigaciones sobre cómo proporcionarles herramientas a los maestros de matemáticas y ciencias para incorporar el lenguaje en la práctica de enseñanza diaria. El presente trabajo respalda el llamado a la atención de las necesidades de todos los maestros de contenido que trabajan con EBs para tener algún entrenamiento en conciencia del lenguaje.

Palabras clave (Fuente: tesauro de la Unesco): enseñanza de matemáticas y ciencia; conciencia lingüística del maestro; práctica docente; bilingües emergentes; objetivos de lenguaje.

RESUMO. O objetivo deste estudo é ilustrar a base linguística das boas práticas de ensino relacionadas às áreas de conteúdo não linguístico, especialmente em relação a objetivos lingüísticos; Usamos uma extensão da metáfora de aprendizado de Tharp e Gallimore: tornar visível o ensino para desenvolver o pensamento dos alunos. No contexto do treinamento pré-serviço e pós-serviço dos professores, examinamos como os professores de ciências secundárias e matemática estruturam seu próprio ensino de acordo com os bilíngues emergentes (EBs). Através de entrevistas e grupos focais, descobrimos que os professores desenvolvem um maior senso da importância dos objetivos da linguagem com o tempo. Um exame das forças e desafios percebidos aponta para a necessidade de uma maior formação de professores na área da sensibilização linguística (TLA). Até agora, a predominância da pesquisa TLA examina as salas de aula dos professores de idiomas (incluindo L2). Com base em nossa análise de como os professores de conteúdo definem e empregam os objetivos de linguagem em seu ensino, propomos uma pesquisa sobre como oferecer aos professores de matemática e ciências ferramentas para incorporar a linguagem na prática pedagógica cotidiana. Este trabalho apoia o convite para atender às necessidades de todos os professores de conteúdo que trabalham com EB para ter algum treinamento em consciência do idioma.

Palavras-chave (Fonte: tesauro da Unesco): ensino de matemática e ciências; consciência linguística do proessor; prática docente; bilíngues emergentes; objetivos de linguagem. 


\section{Introduction}

This study aims to illustrate the linguistic foundation of good teaching practices in content areas, especially mathematics and science. It examines teacher practices through an extension of Tharp and Gallimore's (1988) metaphor of learning: making teaching for developing student thinking visible. The target study examines how secondary-science and math teachers contextualize their own teaching practice, the role they assign to language when teaching these subjects, and what they think about Emergent Bilinguals (EBs) in their content area classes.

This study focuses on language objectives, particularly the way that content area teachers understand their role and make use of language objectives (or not) as a way to contextualize their teaching for learning. Particular attention was given to teachers who have had no explicit training in the use of language objectives with EBs in their classrooms, and also those who have.

\section{School contexts}

Data for this study was collected from the content teachers in public schools in the southwestern part of the United States, who were not language teachers but who were increasingly expected to address the needs of EBs. One consequence of this is the increased concern that content area teachers should adapt their lessons to accommodate their linguistically diverse students because, traditionally, content area teachers/mainstream teachers, have not had any training in working with EBs. A range of different in-service and pre-service professional development (PD) programs, such as Sheltered Instruction Observation Protocol (SIOP), Guided Language Acquisition Design (GLAD), Specially Designed Academic Instruction in English (SDAIE), and Cognitive Academic Language Learning Approach (CALLA) (Chamot \& O'Malley, 1994; Díaz-Rico, 2012; Echevarria, Vogt, \& Short, 2013; O’Donovan, 2008; Wright, 2015), have been introduced as a solution to address the needs of these content teachers. In Europe and Latin America, content and language education is simultaneously addressed through the Content and Language Integrated Learning (CLIL) approach (Cenoz, 2015; Cenoz 
\& Ruiz de Zarobe, 2015; Coyle, Hood, \& Marsh, 2010). However, while many of these training programs provide insights on how to strategically reach EBs through content, they mostly do not focus on language, primarily on language as a tool for teaching and learning.

The field of language awareness provides a model for how content teachers, who now are also "de facto language teachers" (Gottlieb \& Ernst-Slavit, 2013, p. 23) may receive explicit, focused training on addressing the needs of EBs in their classrooms (Garcia, 2008; Gottlieb \& Ernst-Slavit, 2013; Lindahl, 2013). This paper mainly discusses the impact of teacher language awareness (TLA) on teacher practice: how teachers understand and use language objectives as part of their lesson planning and delivery. It further examines how teachers frame their language use in the classroom and presents several preliminary findings of a PD sequence that supports content area teachers in the development of a language awareness perspective when working with EBs.

Content teachers are usually experts in their field, such as mathematics, science, and so on, but by virtue of their job descriptions and training, they have little understanding of language as a tool for teaching and learning. Furthermore, the majority of these content teachers at the secondary level have little understanding of their students' background (e.g., first and second languages, education, or home culture) and their particular learning needs; in other words, they lack knowledge regarding their students' first language (L1) as well as their developing second language (L2). In the bilingual contexts described here, content teachers are expected to adopt a linguistic focus in their lessons. However, secondary school teachers often claim expertise in their disciplines (i.e., math, science, etc.) rather than pedagogy addressing EB students (Gess-Newsome, 2013), that is, English as a Second Language (ESL) pedagogy.

A number of potentials for strengthening their teaching to address EBs is left untapped. These potentials include broadening their view of language as a tool for thinking and expanding their view of students, perceiving them as resources rather than problems. Of particular interest is the extent to which teachers are familiar with concepts, but unfamiliar with methods of applying these concepts to the adaption of their talk, their use of materials, or their outlining of activities in the classroom. In this regard, a language awareness approach can benefit content teachers, helping them to improve their teaching 
while addressing the learners' needs by helping them use language as a tool for thinking and learning (Echevarria, Short, \& Powers, 2006). One way of making thinking visible is through the use of language objectives in content area.

\section{Teacher language awareness and language objectives}

Regarding language awareness in pedagogic aspects, researchers specify the need for attention on TLA, with the aim of understanding how teachers can use language awareness be by. In this context, TLA can be conceptualized in three domains: user domain, teacher domain, and analyst domain (Andrews, 2001, 2003; Wright \& Bolitho, 1993). The analyst domain focuses on knowledge about language, such as its forms and functions: This domain consists of the knowledge about academic language, and its nature is unique in each discipline, such as specific vocabulary and associated grammatical constructions. Academic language is also referred to as Cognitive Academic Language Proficiency or CALP, as coined by Cummins (1979).

The teacher domain includes pedagogical content knowledge, general pedagogical knowledge, teacher expertise, and emotional concerns, such as empathy for EBs. This domain covers areas broadly related to learners rather than the nature of language itself. Meanwhile, the user domain focuses on the specific language proficiency, in addition to the social and pragmatic norms that the teacher, as a user of language, has at their disposal. Language objectives fall under both the analyst and the teacher domains due to the need to identify EBs in knowing and understanding language concepts in addition to find optimum strategies to address them in the daily curriculum (Lindahl, 2013).

In this study, language objectives are defined as statements, focusing on both oral and written language that students need in order to carry out the activities associated with the content objectives of the lesson. Language objectives are closely related to content objectives and are ideally designed to facilitate a students' knowledge and learning, how they learn, and behavioral indicators of displaying that they have learned. Language objectives outline the specific language features that learners must used to talk, read, write, and hear within a lesson in order to achieve their learning goals. Literature, in this regard, lists five types of language objectives: academic vocabulary, language 
skills and functions, language structures or grammar, language learning strategies, and literacy building (Echevarria, Vogt, \& Short, 2013).

The Literature on the use of language objectives by content teachers suggests that academic vocabulary is the primary, or sometimes, the only language objective that content teachers recognize or focus on if they employ language objectives at all (Echevarria, Vogt \& Short, 2013; Wong Fillmore, 2011; Regalla, 2012). Yet, the development of academic proficiency requires far more than simply learning the academic vocabulary in a lesson. As Gottlieb and Ernst-Slavit (2013) suggest, "the difference in purpose, audience, and context results in clear differences in terms of language use in the selection of words, formality, sentence construction, and discourse patterns" (p. 2) across different content areas and content objectives. Regarding the United States context in which English is the de facto (but not the de jure) official language of education, De Jong and Harper (2005) expound:

General education discussions assume English language and U.S.based cultural experiences for all students. For example, the national content standards...describe the disciplinary knowledge base of the content area and good teaching practices but fail to explain the linguistic foundation underlying these effective content classrooms Yet students are expected to learn new information through reading texts, participate actively in discussions, and use language to represent their learning by presenting oral reports and preparing research papers. These extraordinary language and literacy demands remain invisible. [emphasis added]. (p. 102)

Thus, there is a great need to highlight literacy and the language demands of school for both teachers and students.

The aim of this paper is to make those language demands visible, through an exploration of language objectives and their role in the content classroom. In this way, PD focusing on TLA can support teachers' use of language objectives in their content area teaching.

\section{Method}

The current study outlines a challenge for content area teachers, and a new avenue for scholars on language awareness: namely, the ways 
in which TLA can frame pedagogical practices supporting EBs. Drawing on a database of interviews and classroom observations from the target macro studies conducted by the two first authors of this article, the data is presented on two groups of math and science teachers: one group with a PD on addressing the needs of EBs in their mainstream secondary classrooms in the United States, and the others without their PD on TLA.

\section{Research questions}

This study focuses on two research questions: "What is the nature of teachers' use of language objectives based on their participation in PD with a TLA focus?" and "How do teachers' perspectives on language objectives vary based on participation in PD or not?"

\section{Participants}

The sample consisted of the teachers in the middle school, lower secondary, high school, and upper secondary categories. Middle-school students ranged from 11-13 years of age and encompassed grades 6, 7, and 8. High-school students ranged from 14-18 years of age and were from grades 9, 10, 11, and 12. A total of 24 teachers were involved in the macro study within which the current, smaller, study emerged. The teachers were participating in a PD program that focused on language objectives. Out of the total number of teachers (24), only some had had prior experience in working with EBs. All were certified to teach in their designated area of expertise (either science or mathematics), and all taught at least one EB in their classes. The majority (16) of the teachers were teaching in small or rural school districts, and they had limited experience in working with EBs. The rest (8) worked in suburban or urban schools and had more years of experience in working with EBs than the other group.

All participants were teachers in a bilingual environment (Spanish and English) in the southwestern region of the United States and had a teaching experience of four to more than twenty years. All of the teachers were female and all were native speakers of English and not bilingual. None of them had a significant professional development in 
working with EBs prior to the PD experience described here. The student demographics in the districts represented by the teachers varied considerably, but the primary second language spoken by their EBs in all cases was Spanish. This paper highlights experience of only five math and science teachers: Ms. Wesley, Ms. McGee, Ms. Plane, Ms. Rich, and Ms. Carpenter (all of them pseudonyms). They all taught either science or mathematics and had undergone multiple phases of the PD project, including observations, focus groups, and interviews.

Several sources of data informed this study: classroom observations, interviews, and focus group discussions on their pedagogic practices. The course was a 1.5-year-online program consisting of ESL pedagogy, second language acquisition (SLA), multicultural education, and mentoring in the form of graduate coursework. The data consisted of the participants' evaluations on their learning as reported through the university's online educational platform, background, focus group transcriptions, follow-up questionnaires, and examples of language objectives written by trainees of the PD in pre and post training.

\section{Data analysis}

Discourse analysis and content analysis were used to understand the themes related to the role of language in teaching. Specifically, the data was analyzed to learn how teachers build meaning (Gee \& Green, 1998; Gee, 1999) in their understanding of language objectives through interactions and discussions. The collected data was digitally audiotaped, transcribed verbatim, and coded using thematic delineation techniques (Denzin \& Lincoln, 2000). Transcripts of classroom observations and the teachers' language objectives in the PD were also examined.

The data was analyzed to find prominent themes in the observations, interviews, focus group discussions, and follow-up questions. Further analysis of developing language objectives and shifts in teacher practice were drawn from the data gleaned from the teachers involved in PD. A difference between "pre-training"” perspectives on the use of language objectives and post-training perspectives were also studied. These categories are presented in the results. 
For the purpose of the analysis presented in this paper, we examine particular telling examples of: 1) teaching practice, and 2) teachers' characterization of their teaching and their EB students' learning in linguistic (or language-based) terms.

In what follows, an outline is found of a) teachers' (pre-PD) perspectives on use of language objectives, b) professional development trained teachers' perspectives on the use of language objectives, and, c) samples of teachers' classroom practice following PD.

\section{Results}

This section outlines teachers' perspectives on what language objectives are and how these objectives are used by the teachers.

\section{Teachers' perspectives before the PD}

Characteristic examples of how teachers in this study talked about language objectives before participating in TLA training are presented here. In example 1, the sixth-grade (lower secondary) science teacher, Ms. Wesley, outlined her orientation to language objectives.

\section{Excerpt 1. Orientation to language objectives}

"It's required, so we put it on the board because someone's gonna walk in and they're going to put a check mark in their book I have done it."

From this quote, it is evident that Ms. Wesley considers language objectives as an administrative requirement rather than a teaching tool. For her, it seems as if language objectives are not much more than a required component in a lesson plan for EBs. According to the following, she was not alone in her beliefs. In excerpt 2, the ninth-grade (upper secondary) math teacher, Ms. McGee, expresses her desire to use language objectives with her frustration regarding the use of them. 
Excerpt 2. Use of language objectives

"I've had the same language objective on the board for the last three weeks. And I know it's meaningless to me and I'm sure it's meaningless to the kids. But we don't know how to write a good language objective. And l've asked you know, like, "could you please help me figure out a way to actually make it meaningful 'cause I get, in theory, that it could be helpful which is similar to what you just said, I'm both an English teacher and a science teacher, but how do you help science teachers become more aware of how to be English teachers?"

This example shows that Ms. McGee considers her dual role: as an English and science teacher. However, she does not know how to be trained to address her needs in order to move beyond the administrative requirement (writing language objectives on the board). While this teacher acknowledges her responsibility to all of her science students, including the EBs, she feels that she lacks understanding of how to identify and write an appropriate language objective to help them. Her request is a call for help.

Other teachers talked about language objectives in terms of using them as clear teaching tools. In the third example, the seventh-grade (lower secondary) math teacher, named Ms. Plane, talks about objectives and their role in the phrase, "designing what things I'm working on," (in other words, as a tool for planning).

\section{Excerpt 3. Language objectives as clear tools}

"So, for me objectives are really good especially when I'm designing what things I'm working on so if I really want them to do, so today I said 'guys I really want the process. We're not working on multiplying today'. So, the goal is that they understood what the formula means, how to use it, and how to get a result ... So, my connections that I want to be making is the process. So, a lot of times I could have two objectives: the process and the end result."

Her comment reflects that Ms. Plane remains unclear about the distinctions between content objectives and language objectives. She understands objectives as more of a general notion, rather than a tool 
related directly to the forms, functions and mechanics, terminology, and other linguistic conventions of different academic disciplines.

In excerpt 4, the interviewer asks the high-school math teacher, Ms. Carpenter, a sharp question about language objectives, and the teacher provides an innovative understanding of language objectives.

Excerpt 4. Innovative understanding of language objectives

Interviewer: I was going to ask you if you've ever heard of the notion of language objectives because I noticed you don't have language objectives...

Teacher: I don't have them written up there, but I have language objectives, and Carlos has language objectives that have not actually improved as much as Carmen because Carmen's language objectives are different than his 'cause he still has not made it past the mute stage.

Ms. Carpenter conceptualizes language objectives as something that is directly connected to each EB in her class. While she is not completely off track in her understanding of language objectives, she conceptualizes them in a very student-specific way. Ms. Carpenter, then, sees language objectives as a part of an individual student's language proficiency, rather than something directly connected to language that will directly support the lesson content.

The preceding excerpts reveal that teachers without PD felt that language objectives were another expectation placed upon them by their administrators. They did not quite understand the ways in which the objectives are connected to their classroom practice. They did not feel confident using them to highlight the academic language concepts related to the content concepts in math or science. The other two teachers appeared to understand that language objectives were indeed tied to the individual language proficiency of the students and had the potential of being useful in working with EBs, but they still lacked procedural knowledge of how language objectives were used in mainstream classrooms to support content-learning. Either through a lack of specificity or a misunderstanding of how language objectives connect to actual lessons, language objectives were a nonfunctioning concept for these teachers. Because of the teachers' lack of attention on or misunderstanding how language objectives are linked with actual 
lessons, the team delivering the PD course determined not only to facilitate math and science teachers' understanding of what language objectives are and how their use in a mainstream content area course with EBs, but also to include a component on how to write language objectives with the right language awareness in PD.

Figure 1 shows a snapshot of the sixth-grade teacher, Ms. Rich's, content and language objectives on space exploration. It reads that she has the language objective and a higher order-thinking question (a HOT question). It can be noted that the standard and the content objective are exactly the same, but the language objective labeled as $5 G$ has been drawn directly from the language proficiency standards. From the perspective of researchers who support the use of language objectives (e.g. Lindahl \& Watkins, 2014), both the content and the language objectives are far too broad to have any use in the teaching practice around the content, in this case, space exploration.

\section{Figure 1. Objectives on the board}

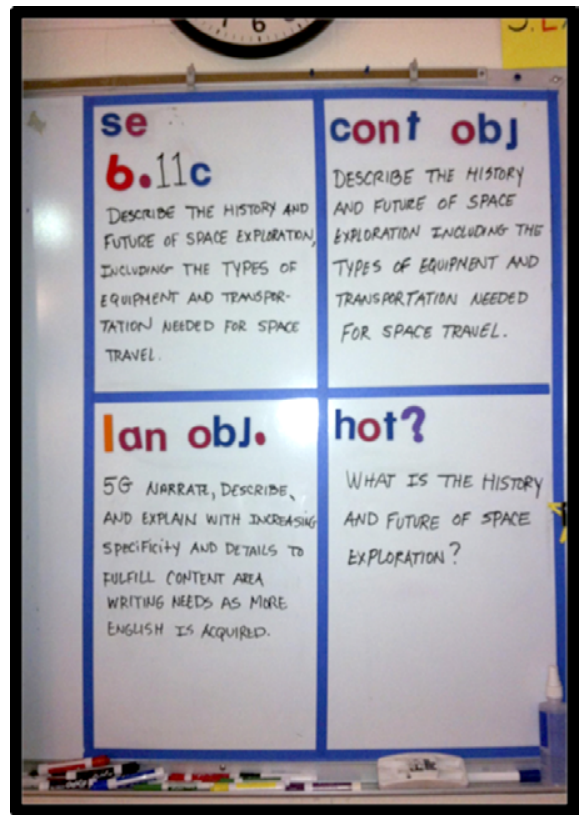

Source: Own image.

In the work with non-ESL specialist teachers, it has been found that writing language objectives is indeed difficult for teachers. As a re- 
sult, language objectives were highlighted in the PD and illustrate how teachers could understand and write appropriate language objectives in their math and science classes.

\section{Teachers' perspectives after PD}

In the next section, we draw on data collected after the teachers had engaged in PD, and provide some evidence for shifts in teachers' awareness and practices following the training. In example $5 \mathrm{a}$, the ninthgrade teacher, Ms. McGee, reflects on how she shifted her use of language objectives, following her explicit training in understanding, crafting and using language objectives.

Excerpt 5a. Shifting thoughts

"I would write something generic, like, 'use math vocabulary' and that was my language objective everyday but then I went to the... training, and they kinda' explained to us that it needs to be something specific...It should be something observable that you can actually see. This helped me plan better too because now I had something, I knew I wanted to see before the class was over."

This response indicates that Ms. McGee has understood the nature of the objective: as related to something specific and observable in students' behaviors during the lesson. She also conceded that her new understanding of language objectives helped her lesson planning. She continues her discussion in excerpt $5 b$ below:

\section{Excerpt 5b. Epiphany}

"That was huge for me as a new teacher 'cause how could you ever know when you're talking to someone, they know what you're saying, if you don't have an observable behavior."

Ms. McGee's reflection of the difference between her pre- and post$\mathrm{PD}$ practice shows how she has realized the value of conscious atten- 
tion to language. Her comment in excerpt 5b, "that was huge for me," shows that she experienced an epiphany in her understanding and use of language objectives.

In excerpt 5c, Ms. McGee talks about how her knowledge about language objectives has benefited her students. This time, however, she laments her previously practiced deviation from not having given conscious attention to language:

\section{Excerpt 5c. Lamentation}

"So I realized I had been teaching a month and a half and I really didn't know, really, for any of the kids, if they really understood until after I gave them a quiz, after like two weeks, most of them fail it and I'm just like wow it would've been nice to know that they needed to know how to do this before I gave them the quiz."

As the old saying goes, "tis useless to regret," Ms. McGee's comment highlights the critical importance of knowing how and why to attend to academic language when teaching content. She has admitted her sorrow of not knowing the need to consider academic language for serving better. Her insights emphasize the necessity of focusing on academic language through language objectives.

In the following section, the examples of teacher created language objectives and how they became more specific, and ultimately effective for both teachers and their students are mentioned.

\section{Examples of language objectives in pre- and post- PD practice}

With training, the teachers began shifting their ways of framing both content and language objectives. Professional development helped the teachers to prioritize the objectives in terms of both language and content and present them in clear expressions (verbally and written) focusing on the lessons. As a result, teachers began to enhance their language objectives by incorporating verbs that prioritized the language. The following examples show the changes in written language objectives before and after the PD. The sequence of steps followed by the teacher called Ms. Rich during the training is below: 


\section{Excerpt 6. Examples of language objectives}

Content objective

- "Describe the history and future of space exploration, including the types of equipment and transportation needed for space travel."

Language objective (pre)

- "Narrate, describe, and explain with increasing specificity and details to fulfill content area writing needs as more English is acquired." Language objective 1 (post)

- "Students will write a descriptive paragraph by incorporating space vocabulary terms from their vocabulary journals." Language objective 2 (post)

- "Students will incorporate transitions to describe change in space travel, such as first, second, third, and last."

The example above shows that the content objective is to "describe the history and future of space exploration, including the types of equipment and transportation needed for space travel." This content objective could certainly serve to define the lessons for several days, but it could also serve as a daily lesson. However, we were primarily concerned with the language to be used within the lesson. The "pre" language objective was very general and did not serve to help students understand the specific language that they would need to describe how space exploration was carried out. There were no details regarding the necessary equipment or transportation (like shuttle, Apollo, or otherwise). The revised (post) language objectives noted above highlight the ways in which Ms. Rich re-framed her objectives. In the first "post" language objective, the teacher has used a descriptive verb, space-related vocabulary, and detailed exactly what the students needed to accomplish with language that particular day. In the second "post" language objective, Ms. Rich again explicitly addresses the use of description and transition words relating to an order of events using ordinal numbers. Detailing the language needed to carry out specific content concepts, as shown in the examples above, can serve not only to promote academic language knowledge and use, but also to outline and highlight important steps that EBs need to carry out their content area learning.

The final example below illustrates a shift in a math teacher's language practice after she had had training in using language objectives. 


\section{Examples of shifts in language practice:}

The following section includes dialogue between the teacher and several students of hers during a middle-school math lesson. The teacher, Ms. Plane, was relating to a previous assignment with the students in order to allow them to discuss and show what they did to solve each problem. The communication between the teacher and her students highlights the ways in which the teacher began to shift her language practice in the classroom, after having training on language awareness and explicit training in using language objectives. This example is related to a warm-up word problem that served as a review of the previously learned material. It aligns with a language-related strategy that the teacher had developed to help students connect language with symbols. As an ongoing activity, her students built a word list in the class, outlining all the symbols and terms found with difficulties.

Figure 2 shows an excerpt from Ms. Plane's copy of the workbook where they regularly listed terms that aligned with mathematical operations. After this problem had been solved on the board, Ms. Plane reminded the students to add the word rest in the column on subtraction in Figure 2, shown in the workbook.

Figure 2. Working with symbols and words for mathematical operations

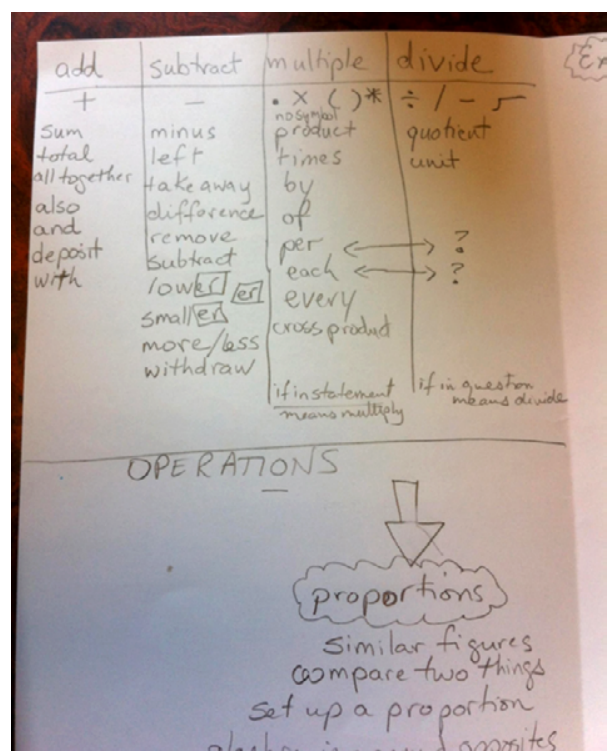


1. T: And number $4,84 \%$ of us got it right, that's awesome, so Peter come explain it.

2. Peter: I got A but I don't know if it's right or not.

3. T: Okay, actually do you see how $C$ is green and it says that $C$ is correct? So what did you do, and we're gonna see where maybe you went wrong, it's okay if you got it wrong.

4. Peter: I multiplied 35 by each of these to see which one is closer to 370.

5. T: Now that was definitely a good strategy but can someone help him out with one thing he might have done at the beginning? Lisa,

6. Lisa: If you subtract 370 and $125 .$.

\section{T: And what let you know that?}

8. Louise: He made a down payment of 125

9. T: He already made a payment and he paid the rest, do you see that word rest, Peter? So circle word "rest", that's what let you know that you needed to subtract, so go ahead and subtract (370-125). Raise your hand if you knew down payment meant you had to subtract. Good cuz that's the first thing and if you got it, good great.

The excerpt above highlights the ways in which Ms. Plane guides her student, Peter, to recognize specific words and phrases that directly connected to particular mathematical operations and procedures. For example, in line 9, the teacher makes rest a key word in the problem. Peter is then directed by the teacher to circle the term rest and reminded that it means he would need to use subtraction.

With the expression, "circle the word rest," Ms. Plane is reminding Peter, that rest typically indicates subtraction because it refers to the idea that there are two or more parts to make a whole. The total given in the problem is $\$ 370$ and then the down payment of $\$ 125$ is made. The total would be $\$ 370$, the down payment of $\$ 125$ would be one part, therefore, leaving one missing part or the "rest" left to find by subtracting the two numbers.

Like this, Ms. Plane incorporates language and content objectives in her lesson to help her students focus on word study (synonyms), language functions (explaining), and vocabulary (subtraction). The language objective here is further utilized as a teaching tool to enhance the lesson, rather than simply a planning tool solely for EBs. This is in sharp 
contrast to what Ms. Wesley states in excerpt 1: The language objective is on the board as an administrative checkmark. These practices reflect the kind of insights expressed by Ms. McGee in excerpt 5a, where language objectives should be something specific, doable, and observable, such as here where the students look for and then record synonyms for mathematical operations.

Later, when Ms. McGee was asked whether she could construct a language objective around this type of activity or not, she suggested the following: Students will be able to explain the mathematical process you used to solve a word problem and point to the specific words we have learned that refer to the operation in question. Going back and reflecting on activities to see how they connect to language objectives, a type of back engineering is an additional strategy that help teachers like Ms. McGee build their TLA.

\section{Discussion}

The observations and interactions with math and science teachers showed that, while required by their school administrators to post and use language objectives as well as content objectives in their classrooms, many teachers have little to no understanding of what it means to involve language objectives into their teaching. Teachers initially thought of content objectives as administrators' expectations-a box to check, rather than as part of their practice. With training, they began to understand that their objectives are connected to their practice and that they can be integrated in the classroom. Reviewing teachers' practices proved that they became aware of focusing on language, but they were neither explicit about it with their students nor consistent.

With the training focused on identifying the language demands needed to carry out math and science activities in their classes, as well as on writing language objectives, content teachers feel more effective in applying this work to their teaching than they were. In doing so, the teachers were able to shift their attention to language. The challenge for teachers without training was that they did not think explicitly about how language is directly connected to what they do and must 
do to what their students must do to be successful. Once they took ownership and rewrote the objectives in their own words, they were able to use it as a tool for improving teaching rather than a task to be completely unrelated to their teaching.

Thus, this study supports the call that Wright and Bolitho (1993) made 25 years ago for teachers "to develop their sensitivity toward language, as part of a strategy aimed at enhancing classroom teaching and learning" (p. 302). However, this sensitivity must also be encouraged in the content areas, so that non-CLIL-trained content teachers begin to shift their conceptualizations of themselves to language teachers as well. In this way, CLIL and content teachers will increase their knowledge base in order to expand their dual roles as content and language teachers (Llinares, Morton, \& Whittaker, 2012).

Professional development for content area teachers without CLIL training can facilitate the teachers' ability to explicitly think about the ways in which language directly connects to their overall, pedagogical practices. Therefore, the authors suggest that the goal of professional development for content area teachers should be to frame their planning in terms of the question: What is the language my students need to succeed on this task?

In order for this to happen, teachers need to be shown what they already know about language. Once teachers have identified what they know about language, the next critical step is for them to make it explicit. Linguistic analyses of their own content are an important skill for teachers (Gibbons, 2009), and they are also an essential component of TLA. Being able to do such analysis makes it possible for teachers to move beyond just vocabulary, focus on strategies, structures, language skills, functions, and word study. Teachers further need to be shown how to tap into their existing knowledge of their content as related to language. When teachers are explicit about what they know about language and prior knowledge, they build language awareness. In other words, teachers and learners think clearly and overt by identifying language demands necessary to accomplish tasks in their science, math, or whichever discipline they work with, and explicitly outline them. Training in TLA with a direct focus on language objectives, then, is a useful and effective component of PD for teachers without training on CLIL. 


\section{References}

Andrews, S. J. (2001). The language awareness of L2 teacher: Its impact upon pedagogical practice. Language Awareness, 10(2-3), 75-79. Retrieved from http://hdl.handle.net/10722/42083

Andrews, S. J. (2003). Teacher language awareness and professional knowledge base of the L2 teacher. Language Awareness, 12(2), 81-95. DOI: 10.1080/09658410308667068

Andrews, S. (2007). Teacher language awareness. Cambridge, UK: Cambridge University Press.

Cenoz, J. (2015). Content-based instruction and content language integrated learning: The same or different? Language, Culture and Curriculum, 28(1), 8-24. DOI: 10.1080/07908318.2014.1000922

Cenoz. J., \& Ruiz de Zarobe, Y. (2015). Learning through a second or additional language: Content-based instruction and CLIL in the twenty-first century. Language Culture and Curriculum, 28(1), 1-7. DOI: 10.1080/07908318.2014.1000921

Chamot, A. U., \& O’Malley, J. M. (1994). The CALLA handbook: Implementing the cognitive academic language learning approach. New York, NY: Addison-Wesley.

Coyle, D., Hood, P., \& Marsh, D. (2010). CLIL. Cambridge, UK: Cambridge University Press.

Cummins, J. (1979). Cognitive/academic language proficiency, linguistic interdependence, the optimum age question and some other matters. Working Papers on Bilingualism, 19, 121-129. Retrieved from https:// www.researchgate.net/publication/234573070_CognitiveAcademic_ Language_Proficiency_Linguistic_Interdependence_the_Optimum_ Age_Question_and_Some_Other_Matters_Working_Papers_on_Bilingualism_No_19

de Jong, E. J. \& Harper, C. (2005). Preparing mainstream teachers for English-language learners: Is being a good teacher good enough? Teacher Education Quarterly, 32(2), 101-124. Retrieved from http://www.teqjournal.org/backvols/2005/32_2/13dejong\&harper.pdf

Denzin, N. K., \& Lincoln, Y. S. (2000). Handbook of qualitative research $\left(^{\text {nd }}\right.$ Ed.). Thousands Oaks, CA: Sage Publications.

Díaz-Rico, L. T. (2012). Teaching English learners: Strategies and methods. Trenton, NJ: Pearson. 
Echevarria, J., Vogt, M., \& Short, D. J. (2013). Making content comprehensible for secondary English learners: The SIOP model. Boston, MA: Pearson Education.

Echevarria, J. Short, D., \& Powers, K. (2006). School reform and standards-based education: A model for English language learners. Journal of Educational Research, 99(4), 195-210. Retrieved from http://edfs200ell.pbworks.com/w/file/fetch/54561001/EchevarriaShort-SchRefSBEELLs.pdf

García, O. (2008). Multilingual language awareness and teacher education. In J. Cenoz \& N. Hornberger (Eds.), Encyclopedia of language and education, (2nd Ed., Vol. 6. pp. 385-400). Berlin, Germany: Springer.

Gee, J. (1999) An introduction to discourse analysis: Theory and method. New York, NY: Routledge.

Gee, J., \& Green, J. (1998). Discourse analysis, learning, and social practice: A methodological study. Review of Research in Education, 23, 119-169. DOI: $10.2307 / 1167289$

Gess-Newsom, J. (2013). Pedagogical content knowledge. In J. Hattie \& E. M. Anderman (Eds.), International guide to student achievement (pp. 257259). New York, NY: Routledge.

Gibbons, P. (2009). English language learners, academic literacy and thinking: Learning in the challenge zone. Portsmouth, NH: Heinemann.

Gottlieb, M., \& Ernst-Slavit, G. (2013). Academic language in diverse classrooms: Promoting content and language learning. Thousand Oaks, CA: Corwin.

Lindahl, K. (2013). Exploring an invisible medium: Teacher language awareness among preservice K12 educators of English language learners (Dissertation). University of Utah, Salt Lake City, United States. UMI Number: 3563406.

Llinares, A., Morton, T., \& Whittaker, R. (2012) The roles of language in CLIL. Cambridge, UK: Cambridge University Press.

Lindahl, K., \& Watkins, N. (2014). What's on the "LO" Menu? Supporting Academic Language Objective Development, The Clearing House. A Journal of Educational Strategies, Issues and Ideas, 87(5), 197-203. DOI: 10.1080/00098655.2014.918531

O’Donovan, E. (2008). Staff development for teachers of English language learners. District Administration, 44, 76-77.

Regalla, M. (2012). Language objectives: More than just vocabulary. TESOL Journal, 3(2), 210-30. DOI: 10.1002/tesj.15 
Tharp, R., \& Gallimore, R. (1988). Rousing minds to life: Teaching, learning, and schooling in social context. Cambridge, UK: Cambridge University Press.

Wong-Fillmore, L. (2011, May). English learners and the common core standards. Presentation to the Council of the Great City Schools Bilingual, Immigrant, and Refugee Populations, Directors' Meeting Las Vegas, NV.

214 Wright, W. E. (2015). Foundations for teaching English language learners: Research, theory, policy, and practice ( $2^{\text {nd }}$ Ed.). Philadelphia, PA: Caslon Publishing.

Wright, T., \& Bolitho, R. (1993). Language awareness: A missing link in teacher education? ELT Journal, 47(4), 292-302. DOI: 10.1093/elt/47.4.292 